الجراحة والولاد دة ـكلية الطب البيطرى ـ-جامسة القاهرة.

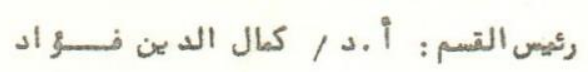

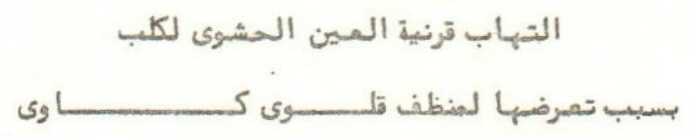

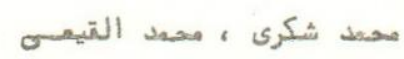

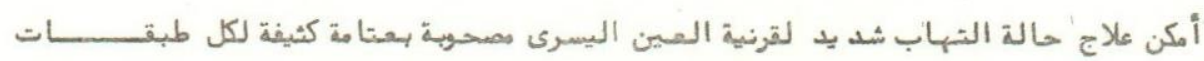

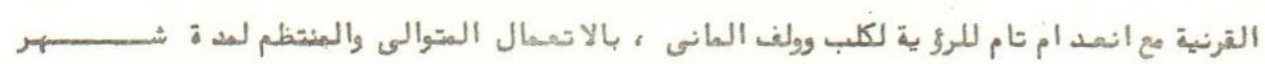

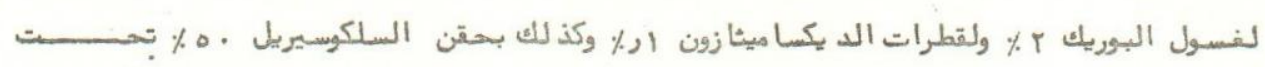

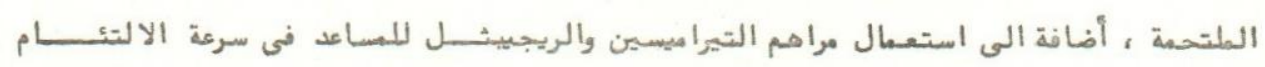

وكانت النتيجة مشجعة للفاية حيث عادنث الروّية لعبين الحسيوان المصاب. 
Dept. of Surgery and Obstetrics.

Faculty of vet. Mied., Cairo University,

Head of Dept. Prof. Dr. K. Fouad.

\title{
LEY DETERGENT AS A CAUSE OF PARENCHYMATOUS KERATITIS IN A DOG \\ (With 3 Figures)
}

By

\author{
M. SHOKRY and M. EL KEIEY \\ (Received at $30 / 5 / 1981$ )
}

A 6-months old male German Shepherd was presented to the Faculty Surgery Clinic at Giza with a history of corneal opacity of the left eye. The animal afflicted with such an ocular injury after accidental exposure to lye detergent. The owner had attempted to treat the condition with a non-prescription ophthalmic medicaments for two days.

Clinical examination and Diagnosis:

The animal was showing unnatural signs manifested by restlessnes, hypersensitivity, viciousness and reluctance to orders. Thorough examination of the affected eye was done after tranquillization with $0.5 \mathrm{mg} . / \mathrm{kg} . \mathrm{l.w} . \mathrm{w}$. Combelen (Bayer) 1.m. Examination of the affected eye revealed blepharospasms, influent tearing, acute conjunctivitis while the cornea showed generalized white dense opacity throughout its layers (leucoma). The visual function of the affected eye was lost (Fig. 1). The case was diagnosed as parenchymatous keratitis due to the irritant effect of the chemical cause.

Prognosis:

The prognosis was unfavourable since the cornea of the affected eye was severely involved and the case is advanced. Therefore the owner was informed that the condition is guarded and absolute cure is far to be obtained, however the patient needs dally attention together with the medical treatment for a long duration.

Treatment:

Initially, measures were taken to neuteralize and counteract the action of the alkaline caustic agent on the affected eye, simply by the application of boric acid eye lotion $2 \%$. Dexamethasone sodium phosphate ${ }^{*} 0.1 \%$ was topically instilled into the affected eye. Solcoseryl $1^{* *}$ eye gel $20 \%$ and Terramycine (Pfizer) ophthalmic ointment were also spread into the conjunctival cul de-sac. The mentioned treatment was applied twice daily for one week.

Thereafter, the treatment comprised sub-confunctival injection of Solcoseryl ${ }^{* *}$ solution $50 \%(0.5 \mathrm{ml}$.$) in$ the dorsal bulbar conjunctiva of the affected eye every other day for another three weeks. In addition, Regepithel* and Terramycine eye ointment were topically applied twice daily throughout the same period.

\section{RESULTS and DISCUSSION}

Having used the previous programe of treatment, encouraging results were achieved. After the first week of treatment marked improvement manifested by reduction of blepharospasms and tenderness, cessation of tearing and progressive resolution of conjunctivitis was noted. Meanwhile the animal regained its natural behaviour and apetite and in general its normal condition.

Such improvement was primarily, due to the ant1-inflamatory action of Dexamethasone together with the tissue-regenerating action of Solcoseryl.

Here, it should be emphasized however, that coticosteroids are indicated for treatment of various forms of keratitis for their anti-inflammatory effect, but they should be used cautiosly if the cornea is ulcerated (MAGRENE, 1955 and SCHMIDT, 1976).

Dexamethasone was discontinued after one week as the signs of inflammation were alleviated. Naturally, the treatment with antibiotic ophthalmic topics was necessary in such a condition in order to protect the inflammed tissues from secondary infection.

* Thilo-0rient West Cermany.

* Solco Basle Ltd. Switzerland.

Assiut Vet.Med.J.Vol. 10, No. 20, 1983. 
The next three weeks of treatment showed progressive and sustained improvenent. By the end of this stage of treatment, the affected cornea showed remarkable transparency except a small localised scar which remained excentric, whilst the iris became visible (Fig. 2 and 3 ). The visual function was markedly restored. The sald promising results were achieved after the subconjuctival injection fo diluted solution of Solcoseryl together with the topical application of Regepithel eye ointment. The clinical parameter relled on vas the degree and extent of corneal transparency.

According to MEYTHALER and PFANN, (1969), Solcoseryl acts directly on oxygen metabolism which is usually insufficient especially in cases of bradytrophia of the cornea. Consequently, the swift restoration of the epithellal activity will promote regeneration of the damaged layers of the cornea.

Many authors; OBERHOLSTER (1967), LAGEMANN (1975) and SHOKRY and GRIGORIADIS (1981) had successfully used Solcoseryl for the treatment of various corneal lesions in animals with varying pronising results. Hence, it must be pointed out that subconjunctival injection of Solcoseryl proved valuable and well tolerated. HAVEUER (1966) and GELATT (1968) found that via subconfunctival injection, the ocular absorption is usually excellent as single subconjunctival injection achieves higher intraocular drug levels than do a few topical applications

As a general rule, such method of treatment can be used in animals when maximum level of a drug is quickly needed and when frequent topical applications appear impracticable.

Regepithel eye ointment which contains those vitamins necessary for corneal nutrition 1.e. vitamin A. aneurine chloride and calcium pantothanate is supposed to be catalytic as more rapid healing was achieved and recurring corneal erosions were avoided.

One can say after reporting on such case that emergency cases of ocular injuries due to chemical caustics might respond effectively to treatment if received early and immediate medical attention is carried out by using proper medicaments and regular aftercare.

\section{REFERENCES}

Gelatt, K.N. (1968): Veterinary Ophthalmic Pharmacology and Therapeutics. 1.A Introduction. VM/SAC, 63: 547553.

Haveuer, H.H. (1966): Dcular Tharmacology. C.V. Mosby, St. Louis.

Lagemann, H. (1975): Beitrag über die Behandlung eines Kalkverätzten Auges beim Hund. Der Praktische Tierarzt. 7: $652-657$

Magrene, W.G. (1955): Vascularization - Its significance in Diseases of the Cornea. J.A.V.M.A., 126: 392-396.

Meythaler, H. und Pfann, J. (1969): Experimentelle und Klinische Erfahrungen mit ACTIHAEMYL bel Kalkverätzungen des Auges. Ber. Dtsch. Opth. Ces. Heldelberg: 59-61.

Oberholster, J.J. (1967): Treatment of Infectious ophthalmia with Solcoseryl and Chloramphenicol. J.S. Afr. Vet. Med. Ass. 38: 111-113.

Schmidt, G.M. (1976): Problem Oriented Ophthalmology. Part 3. Chronic superficial keratitis. MVP, 57: 812-816. Shokry, M. und Grigorladis, P. (1981): Elne wirkungsvolle Therapie von Hornhauterkrankungen der Haustiere mit Solcoseryl. Deutsch. Tierärztl. Wochen. 88: 85-88. 


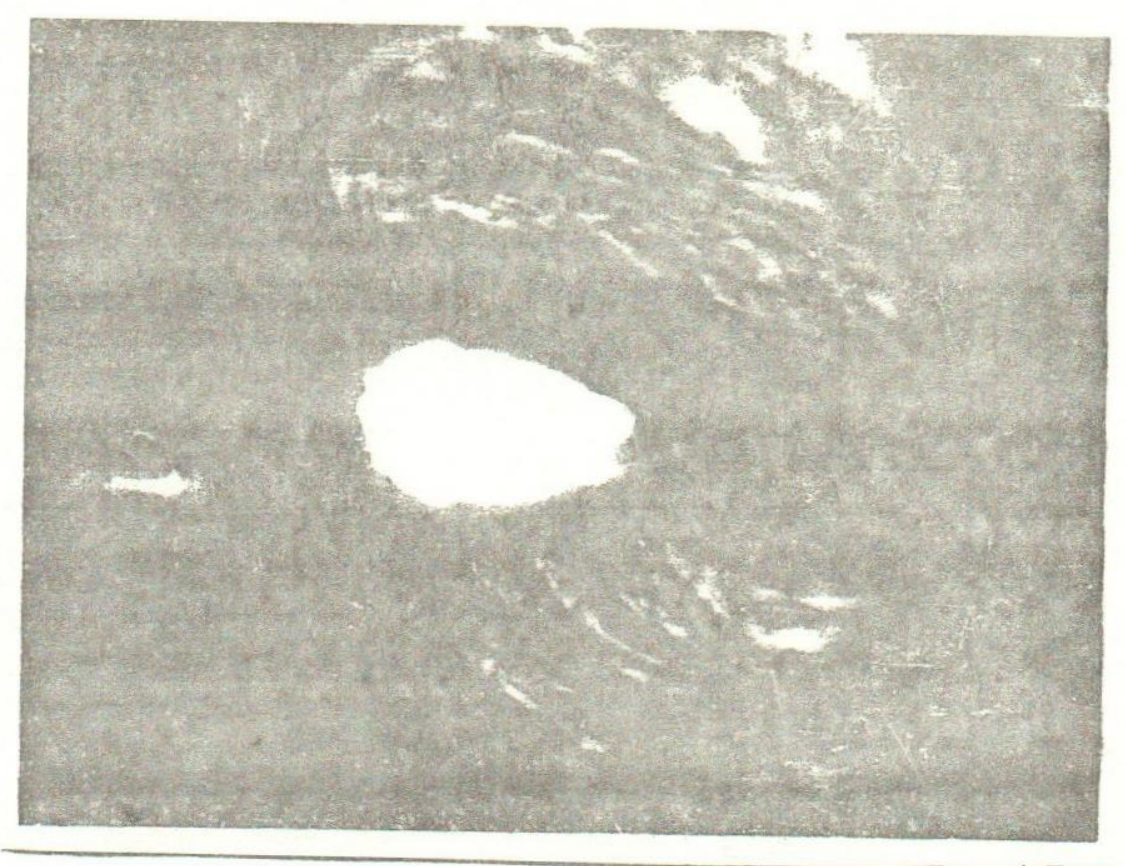

Fig. (1): left eye of 6 months old male dog before treatment. Note generalized white dense opacity of the cornea.

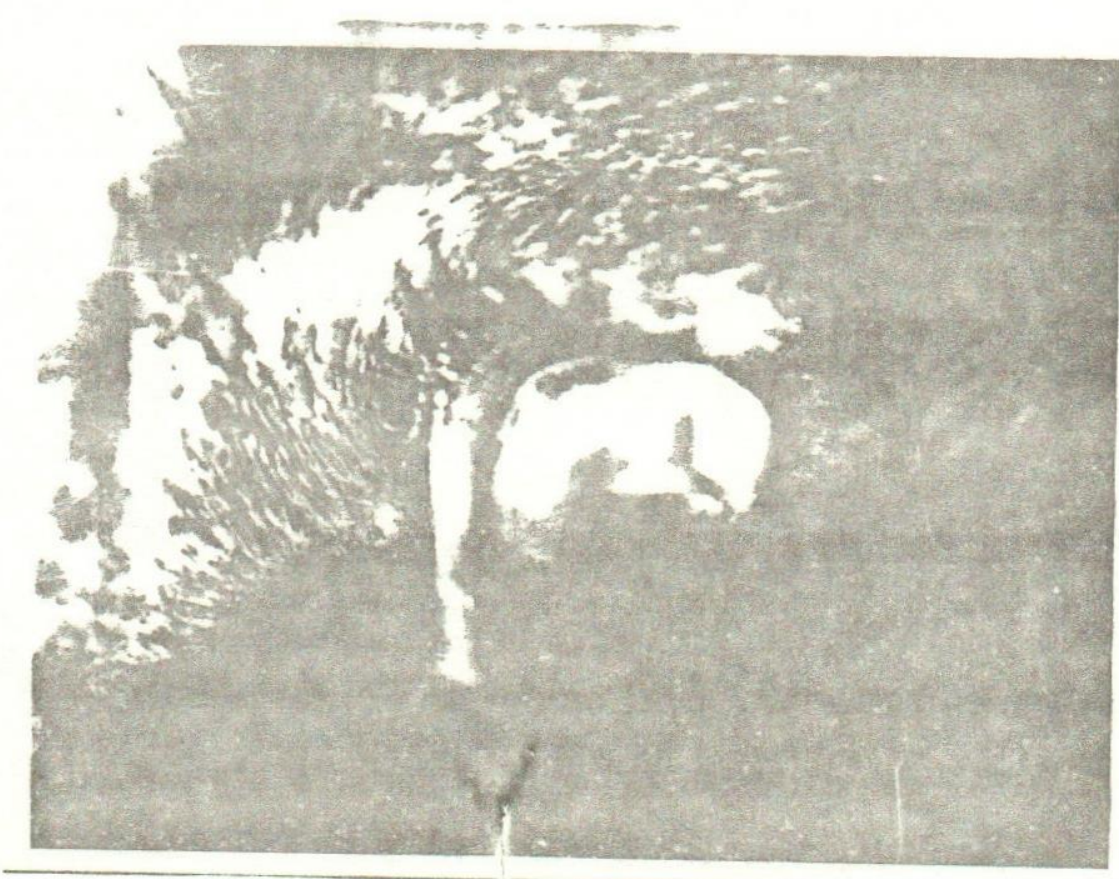

Fig. (2) The same eye. Note partial transparency of the cornea after a 2 weeks treatment. 


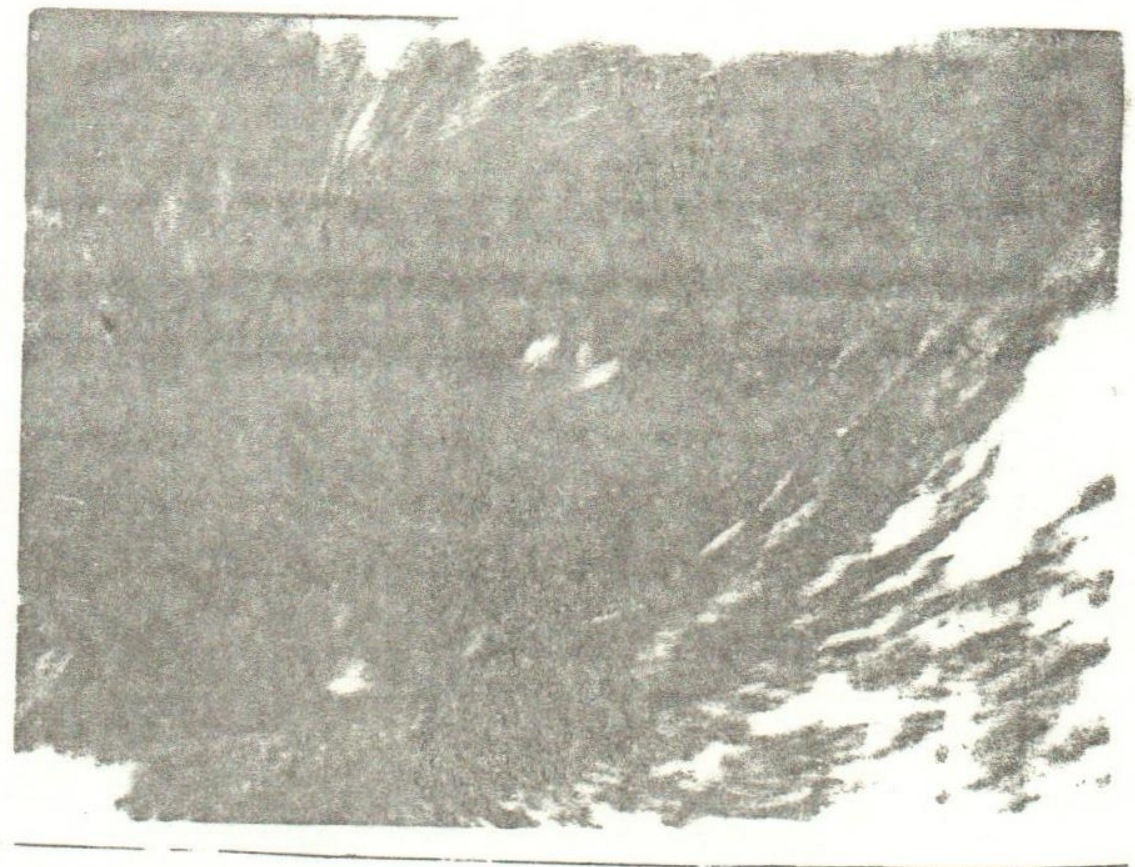

Fig. (3): The same eye. Note marked transparency of the cornea exvept a small excentrically situated localised scar, after a 4 weeks treatment. 
